University for Business and Technology in Kosovo

UBT Knowledge Center

UBT International Conference

2017 UBT International Conference

Oct 28th, 9:00 AM - 10:30 AM

\title{
Determinants of trade in value added: the case of the Central and Eastern European Countries
}

Lukasz Ambroziak

Warsaw School of Economics, la28204@sgh.waw.pl

Follow this and additional works at: https://knowledgecenter.ubt-uni.net/conference

Part of the Business Commons

\section{Recommended Citation}

Ambroziak, Lukasz, "Determinants of trade in value added: the case of the Central and Eastern European Countries" (2017). UBT International Conference. 242.

https://knowledgecenter.ubt-uni.net/conference/2017/all-events/242

This Event is brought to you for free and open access by the Publication and Journals at UBT Knowledge Center. It has been accepted for inclusion in UBT International Conference by an authorized administrator of UBT Knowledge Center. For more information, please contact knowledge.center@ubt-uni.net. 


\title{
Determinants of trade in value added: the case of the Central and Eastern European Countries
}

\author{
Łukasz Ambroziak ${ }^{1}$ \\ ${ }^{1}$ Warsaw School of Economics, Collegium of World Economy, Al. Niepodległości \\ 162, 02-554 Warszawa / Warsaw, Poland \\ la28204@sgh.waw.pl
}

\begin{abstract}
The aim of the paper is to investigate determinants of trade in value added of the CEECs (Bulgaria, the Czech Republic, Estonia, Hungary, Latvia, Lithuania, Poland, Romania, Slovakia and Slovenia) in the period 2000-2014. For this purpose, it uses a generalised gravity model based on panel data. The main independent variables (GDP of trading countries and the distance between them) have the same direction of impact on both value added exports/imports and gross exports/imports. Only the values of coefficients differ. The greatest difference concerns the geographical distance. It results from indirect value added trade.
\end{abstract}

Keywords: trade in value added, gross trade, Central and Eastern European countries, WIOD

\section{Introduction}

The making available in the early 2010s of complex databases containing world input-output tables (e.g. the World Input-Output Database - WIOD) was a significant advancement in research on international trade. It allowed to compile statistics of value added (VA) flows between countries. Trade statistics in VA terms take account of the contributions of particular countries to the creation of VA and eliminate the multiple calculation in trade of components, first separately (as intermediate goods) and then as parts of final goods (OECD, 2013). Thus, trade statistics in VA terms enable us to better estimate trade changes resulting from internationalisation and globalisation as well as benefits derived by countries from international trade.

The concept of 'trade in value added' or 'value added trade' allows to determine how much of the VA created in a country is directly and indirectly embodied in the final consumption of another country (Stehrer, 2013). VA may flow to the destination country directly in the form of the final product or indirectly in the form of a semi-finished product through other countries. It means that the country concerned exports an intermediate product to a country in which it is used for the manufacture of the final product, subsequently exported to the country of destination where it is consumed or absorbed (Johnson and Noguera, 2012).

In order to demonstrate the difference between VA and gross trade balances, Figure 1 presents an example of trade between three countries. The differences between net trade in gross and VA terms result from the possibility that a country may trade with another country only indirectly via a third partner. In the example below, country A exports an intermediate worth 2 to country B, which then - after adding some value of its own - ships the final product worth 3 to $\mathrm{C}$, where it is consumed. Thus, no physical shipment of the good between A and $\mathrm{C}$ is observed, although there is value added created in country A which is finally absorbed in country $\mathrm{C}$. 


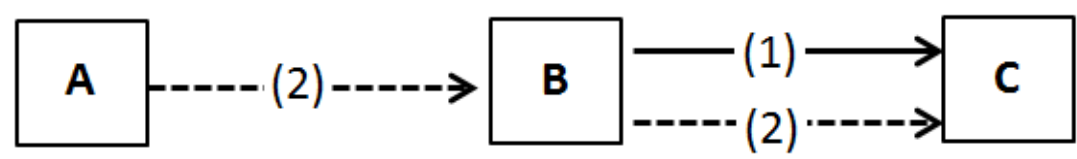

\begin{tabular}{lcc} 
& in gross terms & in VA terms \\
\hline exports of country A to country B & $\mathbf{2}$ & $\mathbf{0}$ \\
\hline exports of country A to country C & $\mathbf{0}$ & $\mathbf{2}$ \\
\hline exports of country B to country C & $\mathbf{3}$ & $\mathbf{1}$ \\
\hline
\end{tabular}

Fig. 3. Illustration of trade in value added Source: Own study based on (Nagengast and Stehrer, 2014; Stehrer and Stöllinger, 2013).

The aim of the paper is to investigate determinants of the trade in value added of the CEECs (Bulgaria, the Czech Republic, Estonia, Hungary, Latvia, Lithuania, Poland, Romania, Slovakia and Slovenia) in the period 2000-2014. For this purpose, it uses a generalised gravity model based on panel data.

\section{Material and methods}

In order to calculate trade flows in value added terms, the World Input-Output Database (WIOD Release 2016) was used. It contains world input-output tables for the years 2000-2014 (Timmer et al., 2016). On the basis of the above-mentioned tables, using the input-output (IO) model, appropriate calculations were made.

The value added exports between country 1 and country $2\left(\mathrm{VAX}^{12}\right)$ are defined as the value added of country 1 which is ultimately absorbed in final demand by country 2 . VAX ${ }^{12}$ are computed in the following way:

$$
V A X^{12}=\left(\begin{array}{lll}
v^{1} & 0 & 0
\end{array}\right)\left(\begin{array}{lll}
l^{11} & l^{12} & l^{13} \\
l^{21} & l^{22} & l^{23} \\
l^{31} & l^{32} & l^{33}
\end{array}\right)\left(\begin{array}{l}
f^{12} \\
f^{22} \\
f^{32}
\end{array}\right)=v^{1} l^{11} f^{12}+v^{1} l^{12} f^{22}+v^{1} l^{13} f^{32}
$$

where:

$v_{i}$ is the value added coefficient of country $i$ of the $1 \times 2464$ value added vector $\mathbf{v}$,

$l^{i j}$ refers to the $i$ th row, $j$ th column element of the $2464 \times 2464$ Leontief inverse $\mathbf{L}$,

$f^{i j}$ denotes flows of final goods from country $i$ to country $j$.

The calculation of the VA imports of country 1 from country 2 is based on the equation allowing to estimate the VA exports of country 2 to country 1 :

$$
V A M^{12}=V A X^{21}=\left(\begin{array}{lll}
0 & v^{2} & 0
\end{array}\right)\left(\begin{array}{lll}
l^{11} & l^{12} & l^{13} \\
l^{21} & l^{22} & l^{23} \\
l^{31} & l^{32} & l^{33}
\end{array}\right)\left(\begin{array}{l}
f^{11} \\
f^{21} \\
f^{31}
\end{array}\right)=v^{2} l^{21} f^{11}+v^{2} l^{22} f^{21}+v^{2} l^{23} f^{31}
$$

In order to investigate the determinants of trade flows of the Central and Eastern European countries, a gravity model was used. Gravity models were developed as a result of employing Newton's law of universal gravitation in the examination of socio-economic phenomena. The 
first researcher to use a gravity model to analyse international trade flows was J. Tinbergen in the 1960s (1962). It followed from that model that the value of trade between two countries was in direct proportion to the product of the countries' gross domestic products and in inverse proportion to the distance between them. Since the 1960s, gravity models have been widely used to analyse trade flows.

The gravity model employed in this study was estimated with the use of the Poisson pseudomaximum-likelihood (PPML) estimator, with a clustering variable - distance. Based on the gravity model proposed by Proença et al. (2015), the gravity equation takes the following form:

$T_{i j t}=\exp \left[\beta_{1} \ln Y_{i t}+\beta_{2} \ln Y_{j t}+\delta^{\prime} \ln X_{i j t}+\phi^{\prime} \ln Z_{i j}+\varphi^{\prime} \ln V_{i j t}+\gamma^{\prime} \ln D_{i j}+\alpha_{t}+\eta_{i j}\right] \varepsilon_{i j t}$

where:

$T_{i j}$ - bilateral trade between country $i$ and $j$ at time $t$ (here: bilateral exports/imports in gross terms and exports/imports in VA terms),

$Y_{i j}-$ GDP of reporter country $i$,

$Y_{j t}-$ GDP of partner country $j$,

$X_{i j t}-$ column vector of non-binary variables (here: diffGDP $P_{i j}$, diffGDPp $c_{i j}$ ),

$Z_{i j}$ - column vector of non-binary time-invariant variable (here: dist $t_{i j}$ ),

$V_{i j t}$ - column vector of binary variables (here: FTApre $_{i j}$, EUmem $_{i j}$, FTApostij, euro $i j$ ),

$D_{i j}$ - column vector of binary time-invariant variables (here: borderij)

$\delta, \phi, \varphi, \gamma-$ column vectors of unknown coefficients,

$\beta_{1}, \beta_{2}-$ unknown scalar coefficients,

$\alpha_{t}-$ time effects,

$\eta_{i j}$ - unobserved heterogeneous effects,

$\varepsilon_{i j t}$ - error term.

Apart from traditional variables included in gravity models (GDP of trading countries and the distance between them), the model also took account of a number of other variables which might influence the value of bilateral trade. Table 1 presents the list of those variables together with their effects on the explained variable as anticipated on the basis of theory and empirical investigations.

The analysis was carried out for bilateral trade between the ten CEECs and their 43 trading partners for the years 2000-2014. The model's estimations were made using the STATA 14 econometric package. The sources of data were as follows: the International Monetary Fund database (World Economic Outlook database), the CEPII (French Research Centre in International Economics) database and the database of the World Trade Organisation (Regional Trade Agreements - International System). 
Table 1. Variables used in the model and their expected effects on dependent variables

\begin{tabular}{|c|c|c|}
\hline Variable & Description & $\begin{array}{c}\text { Expected } \\
\text { impact }\end{array}$ \\
\hline$G D P_{i}$ & $\begin{array}{l}\text { logarithm of reporter country's GDP, current prices, USD } \\
\text { million }\end{array}$ & + \\
\hline$G D P_{i}$ & $\begin{array}{l}\text { logarithm of partner country's GDP, current prices, USD } \\
\text { million }\end{array}$ & + \\
\hline $\operatorname{diffGDP_{ij}}$ & $\begin{array}{l}\text { logarithm of the absolute value of the difference in GDP } \\
\text { between the trading countries }\end{array}$ & - \\
\hline $\operatorname{diffGDPp}_{i j}$ & $\begin{array}{l}\text { logarithm of the absolute value of the difference in GDP per } \\
\text { capita between the trading countries }\end{array}$ & - \\
\hline dist $_{i j}$ & $\begin{array}{l}\text { logarithm of the distance between the capital cities of the } \\
\text { trading countries, in km }\end{array}$ & - \\
\hline border $_{i j}$ & $\begin{array}{l}\text { dummy variable taking a value of } 1 \text { where the trading countries } \\
\text { have a common border }\end{array}$ & + \\
\hline$F T A E U_{i j}$ & $\begin{array}{l}\text { Dummy variable taking a value of } 1 \text { where the trading countries: } \\
\text { - have concluded association agreements with the EU }\end{array}$ & + \\
\hline FTApre $_{i j}$ & $\begin{array}{l}\text { - belong to the same preferential trade group prior to the EU } \\
\text { enlargement in } 2004\end{array}$ & + \\
\hline EUmem $_{i j}$ & - are EU Member States & + \\
\hline FTApost $t_{i j}$ & $\begin{array}{l}\text { - belong to the same preferential trade group as a result of the } \\
\text { adoption of the common commercial policy of the EU upon EU } \\
\text { accession }\end{array}$ & + \\
\hline euro $_{i j}$ & - belong to the euro area & + \\
\hline
\end{tabular}

Source: Own study based on the literature review.

\section{Research results}

It followed from the estimations that the parameters for the three main explanatory variables (GDP of trading countries and the distance between them) in all the estimated equations were statistically significant, whereas the effects of those variables on trade flows appeared to be as expected. GDP growth in the reporter and partner countries had an upward impact on gross and VA exports as well as on gross and VA imports. At the same time, a growing distance between countries pushed down trade flows, whether in gross or VA terms. However, it must be pointed out that the absolute value of the coefficient in the model explaining gross exports (imports) is higher than the absolute value of the coefficient illustrating VA exports (imports). It results from the existence of indirect exports (imports) of value added. It means that the shares of geographically remote countries in trade measured by VA statistics tend to be greater than those in trade measured by traditional statistics. Similar conclusions for Poland's trade in 1995-2011 with the use of data from the Trade in Value Added database were drawn by Folfas (2016). 
Table 2. Results of the estimation of the impact of specific determinants on CEEC trade in 20002014

\begin{tabular}{|c|c|c|c|c|}
\hline Variable & Gross exports & VA exports & Gross imports & VA imports \\
\hline$G D P_{i}$ & $\begin{array}{c}0.887 * * * \\
(0.032)\end{array}$ & $\begin{array}{c}0.934 * * * \\
(0.022)\end{array}$ & $\begin{array}{c}0.801 * * * \\
(0.039)\end{array}$ & $\begin{array}{c}0.811 * * * \\
(0.032)\end{array}$ \\
\hline$G D P_{i}$ & $\begin{array}{c}0.854 * * * \\
(0.052)\end{array}$ & $\begin{array}{c}0.818^{* * *} \\
(0.037)\end{array}$ & $\begin{array}{c}0.941 * * * \\
(0.052)\end{array}$ & $\begin{array}{c}0.94 * * * \\
(0.038)\end{array}$ \\
\hline $\operatorname{diffGDP_{ij}}$ & $\begin{array}{l}-0.009 \\
(0.039)\end{array}$ & $\begin{array}{l}0.003 \\
(0.027)\end{array}$ & $\begin{array}{c}-0.094 * * * \\
(0.036)\end{array}$ & $\begin{array}{c}-0.09 * * * \\
(0.027)\end{array}$ \\
\hline $\operatorname{diffGDPp}_{i j}$ & $\begin{array}{c}-0.109 * * * \\
(0.037)\end{array}$ & $\begin{array}{c}-0.058 * * \\
(0.027)\end{array}$ & $\begin{array}{c}-0.178 * * * \\
(0.04)\end{array}$ & $\begin{array}{c}-0.132 * * * \\
(0.033)\end{array}$ \\
\hline dist $_{i j}$ & $\begin{array}{c}-0.885^{* * *} \\
(0.128)\end{array}$ & $\begin{array}{c}-0.726 * * * \\
(0.079)\end{array}$ & $\begin{array}{c}-0.833 * * * \\
(0.126)\end{array}$ & $\begin{array}{c}-0.769 * * * \\
(0.098)\end{array}$ \\
\hline border $_{i j}$ & $\begin{array}{c}0.633 * * * \\
(0.16)\end{array}$ & $\begin{array}{c}0.526^{* * *} \\
(0.099)\end{array}$ & $\begin{array}{c}0.705 * * * \\
(0.174)\end{array}$ & $\begin{array}{c}0.55 * * * \\
(0.16)\end{array}$ \\
\hline$F_{T A E U_{i j}}$ & $\begin{array}{c}0.897 * * * \\
(0.21)\end{array}$ & $\begin{array}{c}0.55^{* * *} * \\
(0.145)\end{array}$ & $\begin{array}{c}0.449 * * \\
(0.219)\end{array}$ & $\begin{array}{l}0.372 * \\
(0.192)\end{array}$ \\
\hline FTApre $_{i j}$ & $\begin{array}{c}0.711 * * * \\
(0.203)\end{array}$ & $\begin{array}{c}0.439 * * * \\
(0.145)\end{array}$ & $\begin{array}{c}0.169 \\
(0.231)\end{array}$ & $\begin{array}{l}0.154 \\
(0.209)\end{array}$ \\
\hline EUmem $_{i j}$ & $\begin{array}{c}0.961 * * * \\
(0.213)\end{array}$ & $\begin{array}{c}0.446 * * * \\
(0.139)\end{array}$ & $\begin{array}{c}0.371 \\
(0.231)\end{array}$ & $\begin{array}{l}0.075 \\
(0.198)\end{array}$ \\
\hline FTApost $_{i j}$ & $\begin{array}{c}0.400 * * \\
(0.196)\end{array}$ & $\begin{array}{l}0.074 \\
(0.129)\end{array}$ & $\begin{array}{l}-0.288 \\
(0.231)\end{array}$ & $\begin{array}{c}-0.375 * \\
(0.194)\end{array}$ \\
\hline euro $_{i j}$ & $\begin{array}{l}-0.362 \\
(0.226)\end{array}$ & $\begin{array}{c}-0.311 * * \\
(0.152)\end{array}$ & $\begin{array}{c}-0.414 * \\
(0.215)\end{array}$ & $\begin{array}{c}-0.449 * * * \\
(0.174)\end{array}$ \\
\hline const. & $\begin{array}{c}3.924 * * * \\
(0.841)\end{array}$ & $\begin{array}{c}2.173 * * * \\
(0.582)\end{array}$ & $\begin{array}{c}5.172 * * * \\
(0.958)\end{array}$ & $\begin{array}{c}3.949 * * * \\
(0.891)\end{array}$ \\
\hline $\mathrm{R} 2$ & 0.8949 & 0.9322 & 0.8513 & 0.8888 \\
\hline
\end{tabular}

Note: $(*),(* *)$ and $(* * *)$ mean statistical significance at the level of $10 \%, 5 \%$ and $1 \%$, respectively.

Standard errors are in parentheses.

Source: Own calculations.

The effect of differences in GDP between trading countries was only negative and statistically significant for gross imports and VA imports. As regards gross exports and VA exports, it was insignificant statistically. Both export and import flows were pushed down by widening differences in GDP per capita between trading countries. Simultaneously, the existence of a common border between trading partners was conducive to increased trade flows between them. As in the case of the distance, the coefficient value for the border variable in the model explaining gross exports (imports) was higher than the absolute value of the coefficient illustrating VA exports (imports). It corroborates the prior finding of the existence of indirect trade in value added between countries.

Interesting conclusions can be drawn from the analysis of parameters for the variables concerning preferential trade agreements. The effects of association agreements with the then European Communities entered into by the CEECs in the mid-1990s, of the CEECs' EU membership and of other trade agreements concluded by the CEECs before EU accession (the variables FTAEU 
and $m e m E U$ respectively) on gross exports and VA exports were positive and statistically significant at the level of $1 \%$. Free trade agreements resulting from the adoption of the EU common commercial policy had a positive and statistically significant (at the level of 5\%) impact only on gross exports, whereas their effect on VA exports appeared to be statistically insignificant. Contrary to expectations, the influence of two countries' belonging to the euro area on VA exports proved to be negative and statistically significant.

With regard to imports, positive and statistically significant effects (although at a level not greater than 5\%) were found in the case of association agreements with the then European Communities on gross imports and value added imports of the CEECs. Simultaneously, free trade agreements resulting from the adoption of the common commercial policy of the EU appeared to have a negative impact on VA imports, whereas the euro-area membership pushed down import flows measured using either method. Therefore, the findings were inconsistent with the theory and expectations as those suggested a favourable effect on trade of reduced barriers to trade.

\section{Conclusions}

According to the analysis carried out, for most variables the direction of impact on gross exports/imports and on value added exports/imports was identical. Simultaneously, the parameters for variables estimated in the models explaining gross trade and value added trade showed different values. The greatest differences were found in the case of the distance between countries. The absolute value of the coefficient in the model explaining gross exports (imports) was higher than the absolute value of the coefficient illustrating VA exports (imports). It results from the existence of indirect exports (imports) of value added.

In addition, the determination coefficient value in the model explaining VA exports/imports is greater than in the model explaining gross exports/imports. Since GDP is also the sum of value added (rather than gross value) the model containing the explained variable and explanatory variables measured in value added terms is a model of better quality.

Acknowledgements This article is a result of the research project financed by the National Science Centre, decision number: DEC-2014/13/D/HS4/01426.

\section{References}

1. Folfas P. (2016), Handel międzynarodowy mierzony wartością brutto i wartością dodana analiza porównawcza [International trade measured by gross value and value added comperative analysis]. Warsaw: Warsaw School of Economics.

2. Johnson, R.C., \& Noguera, G. (2012), Accounting for intermediates: Production sharing and trade in value-added. Journal of International Economics, 86(2), 224-236.

3. Nagengast, A.J., \& Stehrer, R. (2014), Collateral imbalances in intra-European trade? Accounting for the differences between gross and value added trade balances. $E C B$ Working Paper Series, no 1695, July.

4. OECD (2013), Interconnected Economies: Benefiting from Global Value Chains, OECD Publishing.

5. Proença, I. et al. (2015), Semi-mixed effects gravity models for bilateral trade. Empirical Economics, 48 (1), 361-387. 
6. Stehrer, R. (2013), Accounting Relations in Bilateral Value Added Trade. wiiw Working Papers, 101.

7. Stehrer, R., \& Stöllinger, R. (2013), Positioning Austria in the Global Economy: Value Added Trade, International Production Sharing and Global Linkages. FIW-Research Reports, 2.

8. Timmer M. P. et al. (2016), An Anatomy of the Global Trade Slowdown based on the WIOD 2016 Release, GGDC research memorandum number 162, University of Groningen.

9. Tinbergen, J. (1962), Shaping the World Economy: Suggestions for an International Economic Policy. New York: Twentieth Century Fund. 